Original Research Paper

\title{
Screening of Multi-Drug and Metal Resistant Aeromonas Species from Diverse Sources
}

\author{
${ }^{1}$ Ramasamy Amsaveni, ${ }^{1}$ Muthusamy Sureshkumar, ${ }^{1}$ Joseph Reshma ${ }^{1}$ Mary, Umapathy Indra and \\ ${ }^{2}$ Govindasami Vivekanandhan \\ ${ }^{I}$ Department of Biotechnology, Kongunadu Arts and Science College, Coimbatore-641029, Tamilnadu, India \\ ${ }^{2}$ Farmer's Bio-Fertilizers and Organics 461, Sri Ragavendra Gardens Subramaniampalayam Road G.N. Mills Post \\ Coimbatore-641 029, India
}

Article history

Received: 23-03-2015

Revised: $15-06-2015$

Accepted: 23-07-2015

Corresponding Author:

G. Vivekanandhan

Farmer's Bio-Fertilizers and Organics 461, Sri Ragavendra

Gardens Subramaniampalayam Road G.N. Mills Post

Coimbatore - 641 029, India

Department of Biotechnology, Kongunadu Arts and Science

College, Coimbatore-641029,

Tamilnadu, India

E-mail: aerovivek@yahoo.com

\begin{abstract}
The abuse of antibiotics in the modern era, lead the microorganisms to develop resistance. Antibiotic resistance becomes the part of natural selection in bacteria which allows them to survive in different environments. Bacteria like Aeromonas are able to adapt to changes in the environment such as an increase in antibiotic concentration, which often results in the development of mutations allowing them to survive in unfavourable conditions. The origin of antibiotic resistance in the environment is relevant to human health and there is an urgent need for predicting emerging resistant pathogenic microorganisms. As Aeromonas sp. has been reported as emerging pathogen, the multi-drug resistance was screened for the Aeromonas isolates obtained from fish intestine, clinical and environmental sources, against commercially available antibiotics and it was found that $95 \%$ of the isolates developed resistance towards atleast one antibiotic. The emergence of antibiotic resistance in bacterial populations is a relevant field of study in molecular and evolutionary biology as well as in medical practice. The minimum inhibitory concentration of metals were performed for the isolates and it revealed that silver nitrate at $250 \mu \mathrm{M}$ and copper sulphate at $8 \mathrm{mM}$ concentration inhibited the growth of isolates. Further the metal resistance encoding genes, silP and $\operatorname{cop} \mathrm{A}$ were screened and it was found to be positive in $70 \%$ and $43 \%$ of the isolates, respectively.
\end{abstract}

Keywords: Aeromonas, Antibiotic Resistance, Metal Resistance

\section{Introduction}

Bacteria are among the most diverse living organisms and have adapted to a great variety of environments including the human body (Pizzaro-Cerda and Cossart, 2006). Aeromonas spp. are water-borne and food-borne, Gram-negative rods and oxidase positive bacteria. The $9^{\text {th }}$ edition of "Bergey's Manual of Determinative Bacteriology" classified Aeromonas into two main groups; the psychrophilic non motile and the mesophilic motile aeromonads (Parker and Shaw, 2010). Aeromonas have a broad host range and often been isolated from humans with diarrhoea (Ashdown and Koehler, 1993).

Sinha et al. (2004) in a study observed that the majority of Aeromonas strains exhibited a multidrugresistance profile and this presents a significant threat to management of Aeromonas mediated diarrhoea. Multiple drug resistance among Aeromonas sp. has been reported from many parts of the world (Ko et al.,
1996). Multiple Antibiotic Resistance (MAR) has been registered for $A$. hydrophila isolated from freshwater fish farms in association with a variety of drugs, commonly used as feed additives (Pettibone et al., 1996; Vivekanandhan et al., 2002). The universal and often indiscriminate use of antibiotics in human and animal medicine, including aquaculture, has brought serious consequences in the emergence of resistant strains of Aeromonas (Alvarez et al., 2004).

Levy (1992) stated that the over-reliance on the antibiotic agents made us to treat symptoms normally handled by our body's own immune system. The consequence to this reliance on antibiotic therapy was that bacteria developed ways to resist them. These strains reproduced and their offspring were also resistant, capable of causing infections not cured by antibiotic drugs. The increase in antimicrobial resistance poses a growing challenge in the treatment of Aeromonas infections (Lee et al., 2008). 
Metals are directly or indirectly involve in all aspects of growth, metabolism and differentiation (Beveridge and Doyle, 1989). Heavy metal and antibiotic resistant competence of $A$. hydrophila have been studied by many researchers (Chandra and Monica, 2011; Odeyemi et al., 2012). Heavy metals are stable and persistent environmental contaminants since they cannot be degraded or destroyed. Therefore, they tend to accumulate in soils and sediments (Montuelle et al., 1994). In Tunisia, the persistence and proliferation of antibiotics and heavy metals resistance in bacterial pathogens, belonging to the A. hydrophila, in aquatic environments represents a considerable public health concern (Saidi et al., 2013). The structural and functional characteristics of antibiotic resistance share common themes with those of metal resistance (Baker-Austin et al. 2006). Woods et al. (2009) investigated the prevalence of silver resistance genes in 172 bacterial strains isolated from both human and equine wounds. They performed Polymerase Chain Reaction (PCR) screening for 8 genes, silЕ, silRS, silP, silCBA and $s i l \mathrm{~F}$.

\section{Materials and Methods}

\section{Sample Collection and Processing}

Fish specimens were randomly collected from fish retail outlets in sterile polyethylene bags and brought to the laboratory using an ice chest in less than an hour. The clinical diarrhoeal samples were collected from various hospitals in and around Coimbatore city, Tamil Nadu, India and transported to laboratory using Stuart's transport medium. Subsurface soil samples were collected from mangrove region of Muthupettai, Tamil Nadu, India in sterilized plastic bags and transported to the laboratory. The samples were enriched and streaked on starch ampicillin agar medium (SAA) and incubated for $24 \mathrm{~h}$ at $37^{\circ} \mathrm{C}$. A characteristic yellow to honey coloured colonies were selected and used for further testing.

\section{Isolation of Presumptive Aeromonas Isolates}

After enrichment and streaking onto SAA, honey colored colonies were selected for enzymatic tests which includes oxidase and catalase. The oxidase and catalase positive colonies were then purified by repeated streaking on the nutrient agar and were maintained in the nutrient agar slants.

\section{Genotypic Identification of Aeromonads}

PCR was done for screening of the $16 \mathrm{~S}$ rRNA and $r n p \mathrm{~B}$ housekeeping genes by using genus specific primers with the expected amplicon size of 1050 bp and $410 \mathrm{bp}$ respectively. The primer sequence was tabulated in Table 1. PCR of $10 \mu \mathrm{L}$ reaction was performed with one isolate to optimize the conditions and a $15 \mu \mathrm{L}$ reaction was performed for all the isolates. The PCR conditions followed are presented in Table 2. Each reaction was carried out using $7 \mu \mathrm{L}$ of PCR master mix (Ampliqon, Denmark), $3 \mu \mathrm{L}$ of nuclease free water, 1.5 $\mu \mathrm{L}$ of each forward and reverse primers $(10 \mathrm{pM})$ and $2 \mu \mathrm{L}$ of template DNA (50ng).

\section{Antibiotic Sensitivity Test}

Antibiotic sensitivity was tested for all the isolates used in this study. The antibiotics that are commonly used for the infection control such asAmoxyclav (30 mcg), Aztreonam (30mcg), Cefpodoxime (10mcg), Cephalothin (30 mcg), Chloramphenicol (30mcg), Gentamicin (10mcg), Rifampicin (5mcg), Streptomycin $(25 \mathrm{mcg})$, Tetracycline $(30 \mathrm{mcg})$, Vancomycin $(10 \mathrm{mcg})$ were selected for the present study. Antibiotic sensitivity test was carried out by disc diffusion method (Jorgensen and Ferraro, 2009). Muller Hinton agar (HiMedia, India) was prepared, sterilized and poured onto sterile petriplates. Pure cultures grown in nutrient broth were swabbed on the MHA plates and using antibiotic disc dispenser, discs were placed on the agar surface. After the incubation at $37^{\circ} \mathrm{C}$ for $18-24 \mathrm{~h}$, the diameter of the inhibition zone was measured and compared with the interpretative chart provided by the manufacturer.

\section{Minimum Inhibitory Concentration (MIC)}

\section{MIC for Silver Nitrate (AgNO3. 6H2O)}

MIC for silver nitrate was tested with Luria-Bertani (LB) agar. A wide range of silver nitrate concentrations were used to find out the MIC values. LB agar with silver nitrate concentrations like $0 \mu \mathrm{M}, 10 \mu \mathrm{M}, 30 \mu \mathrm{M}$, $50 \mu \mathrm{M}, 100 \mu \mathrm{M}, 150 \mu \mathrm{M}, 200 \mu \mathrm{M}$ and $250 \mu \mathrm{M}$ were prepared by adding appropriate volume of silver nitrate from the stock. Overnight culture was diluted up to $10^{-8}$ bacterial cells $/ \mathrm{mL}$ in sterile PBS solution. Dilutions of $10^{-6}, 10^{-7}$ and $10^{-8}$ were inoculated as spots $(5 \mu \mathrm{L})$ on the surface of plates using a micropipette. Plates were incubated at $37^{\circ} \mathrm{C}$ for $24 \mathrm{~h}$ and were observed for growth.

\section{MIC for Copper Sulphate (CuSO4.5H2O)}

LB agar with copper sulphate concentrations like 0 $\mathrm{mM}, 1 \mathrm{mM}, 2 \mathrm{mM}, 3 \mathrm{mM}, 4 \mathrm{mM}, 5 \mathrm{mM}, 6 \mathrm{mM}$ and 7 $\mathrm{mM}$ were prepared. It was allowed to cool to $45-50{ }^{\circ} \mathrm{C}$ and appropriate volume of copper sulphate from stock was added to the medium to get the required concentration. The content of the flask was mixed well and poured into sterile petriplates. The overnight culture was diluted to $10-8$ bacterial cells $/ \mathrm{mL}$ in sterile PBS solution. Dilutions of $10^{-6}, 10^{-7}$ and $10^{-8}$ were inoculated as spots $(5 \mu \mathrm{L})$ on the plates with copper sulphate using micropipette. Plates were incubated at $37^{\circ} \mathrm{C}$ for $24 \mathrm{~h}$ and were observed for bacterial growth. 
Table 1. Primers used in this study

\begin{tabular}{|c|c|c|c|}
\hline S. No. & Genes & Primer sequence & Base pairs \\
\hline \multirow[t]{2}{*}{1} & 16S rRNA & F-5' CAGAAGAAGCACCGGCTAAC 3' & 1050 \\
\hline & & R-5' TTACCTTATTACGACTTCAC 3' & \\
\hline \multirow[t]{2}{*}{2} & $r n p \mathrm{~B}$ & F-5' TGGGCAATCGCTGCTTCGT 3' & 400 \\
\hline & & R-5' AGGTCGGAGTCGGCCTGTAA 3' & \\
\hline \multirow[t]{2}{*}{3} & silP & F 5'- AGTGCAACACAACAAC 3' & 1200 \\
\hline & & R 5'- ACTTTCTCTGCACGGA 3' & \\
\hline \multirow[t]{2}{*}{4} & $\operatorname{copA}$ & F 5'- CTTTACGGACTTTTACCCGCC 3' & 1300 \\
\hline & & R 5'- GCGGCGGCCGCCTTTGGGAAGTTGAAAAC 3' & \\
\hline
\end{tabular}

Table 2. PCR conditions for the amplification of genes

\begin{tabular}{|c|c|c|c|c|c|c|c|}
\hline \multirow[b]{2}{*}{ S. No. } & \multirow[b]{2}{*}{$\begin{array}{l}\text { Genes } \\
\text { amplified }\end{array}$} & \multicolumn{6}{|l|}{ PCR conditions } \\
\hline & & $\begin{array}{l}\text { Initial denaturation } \\
\left({ }^{\circ} \mathrm{C}\right)\end{array}$ & $\begin{array}{l}\text { Denaturation } \\
\left({ }^{\circ} \mathrm{C}\right)\end{array}$ & $\begin{array}{l}\text { Annealing } \\
\left({ }^{\circ} \mathrm{C}\right)\end{array}$ & $\begin{array}{l}\text { Extension } \\
\left({ }^{\circ} \mathrm{C}\right)\end{array}$ & $\begin{array}{l}\text { Final extension } \\
\left({ }^{\circ} \mathrm{C}\right)\end{array}$ & $\begin{array}{l}\text { No. of } \\
\text { cycles }\end{array}$ \\
\hline 1 & 16sr RNA & $95^{\circ} / 5 \mathrm{~min}$ & $94^{\circ} / 30 \mathrm{sec}$ & $52 \% / 30 \mathrm{sec}$ & $72 \% / 1 \mathrm{~min}$ & $72 \% / 5 \mathrm{~min}$ & 30 \\
\hline 2 & $r n p \mathrm{~B}$ & $95^{\circ} / 5 \mathrm{~min}$ & $94^{\circ} / 30 \mathrm{sec}$ & $54.5^{\circ} / 30 \mathrm{sec}$ & $72 \% / 1 \mathrm{~min}$ & $75^{\circ} / 5 \mathrm{~min}$ & 30 \\
\hline 3 & silP & $96 \% / 4 \min$ & $96^{\circ} / 20 \mathrm{sec}$ & $54.2^{\circ} / 20 \mathrm{sec}$ & $72^{\circ} / 2 \mathrm{~min}$ & $72 \% / 5 \min$ & 35 \\
\hline 4 & $\operatorname{copA}$ & $95^{\circ} / 5 \mathrm{~min}$ & $95 \% 1 \mathrm{~min}$ & $50.7^{\circ} / 40 \mathrm{sec}$ & $72^{\circ} / 1 \min$ & $72 \% 10 \mathrm{~min}$ & 35 \\
\hline
\end{tabular}

\section{Detection of Metal Resistance Gene}

PCR amplification of silP and copA was performed by using specific primers. The primers used in this study and reaction conditions were tabulated in Table 1 and Table 2.

\section{Results}

\section{Incidence of Aeromonas from Various Sources}

The incidence of Aeromonas spp. was recorded in the intestine of marine fish, soil and clinical (diarrhoeal) sources. A total of 130 samples were processed and 88 samples i.e., 68\% showed positive for Aeromonas. Of the positive Aeromonas isolates, $79 \%$ were from fish intestine, $53 \%$ from soil and $31 \%$ isolates were of clinical origin (Table 3 and Fig. 1).

\section{Antibiotic Sensitivity Assay}

Multidrug resistance was shown by most of the isolates. Maximum level of resistance was shown to cephalothin by most of the isolates and least percentage of resistance was shown towards aztreonam. All the isolates were sensitive to chloramphenicol and gentamicin. Aeromonas isolates obtained from fish, of about $68 \%, 61 \%, 76 \%$ and $75 \%$ were found to be resistant to amoxyclav, cefpodoxime, cephalothin and vancomycin, respectively. Soil isolates of about 94\%, $78 \%, 83 \%$ and $83 \%$ were found to be resistant to amoxyclav, cefpodoxime, cephalothin and vancomycin, respectively. About $100 \%, 82 \%, 91 \%$ and $100 \%$ of clinical isolates were found to be resistant to amoxyclav, cefpodoxime, cephalothin and vancomycin, respectively). With regard to amoxyclav, cefpodoxime, cephalothin and vancomycin, higher frequency of antibiotic resistance was recorded among the clinical isolates.

\section{Resistance Pattern}

The isolates exhibited 29 different resistance patterns. Among the total isolates, $95 \%$ showed resistance to atleast one antibiotic. Two of the isolates obtained from fish showed resistance towards a single antibiotic. The F55 isolate showed resistance towards a maximum of seven antibiotics. Four of the isolates (F56, S70, C83 and C84) were found to be resistant towards six antibiotics with 3 different resistance patterns. About $17 \%$ of the isolates developed resistance against five antibiotics with 5 patterns of resistance. Further $33 \%$ of the isolates showed resistance to about 4 antibiotics with six patterns and about $26 \%$ of the isolates shown resistance to three antibiotics with 9 different patterns for the antibiotics used. The multiple antibiotic resistance is prominent among fish isolates when compared with the soil and clinical isolates.

\section{MAR Index of the Isolates}

The MAR index value of all the isolates ranged from 0.2 to 0.7 . MAR index of 0.2 to 0.3 was exhibited by $40 \%$ of the isolates. MAR index of 0.4 to 0.5 and 0.6 to 0.7 was exhibited by $54 \%$ and $6 \%$ of the isolates, respectively. The MAR index in the range of 0.2 to 0.3 was shown by $41 \%, 28 \%$ and $37 \%$ of the fish, soil and clinical isolates, respectively. About $46 \%, 67 \%$ and $45 \%$ of the respective fish, soil and clinical isolates showed the MAR index ranging from 0.4 to 0.5 . Very few isolates showed the MAR index ranging from 0.6 to 0.7 , which includes $3 \%, 6 \%$ and $18 \%$ of the fish, soil and clinical isolates, respectively. About $10 \%$ of the sensitive isolates were recorded among fish isolates. None of the soil and clinical isolates exhibited MAR index $<0.2$. 
Table 3. The percentage of incidence of Aeromonas spp.

\begin{tabular}{llll}
\hline Samples & No. of samples & No. of samples positive & Percentage of incidence \\
\hline Fish & 75 & 59 & 79 \\
Soil & 34 & 18 & 53 \\
Clinical & 35 & 11 & 31 \\
Total & 130 & 88 & 68 \\
\hline
\end{tabular}
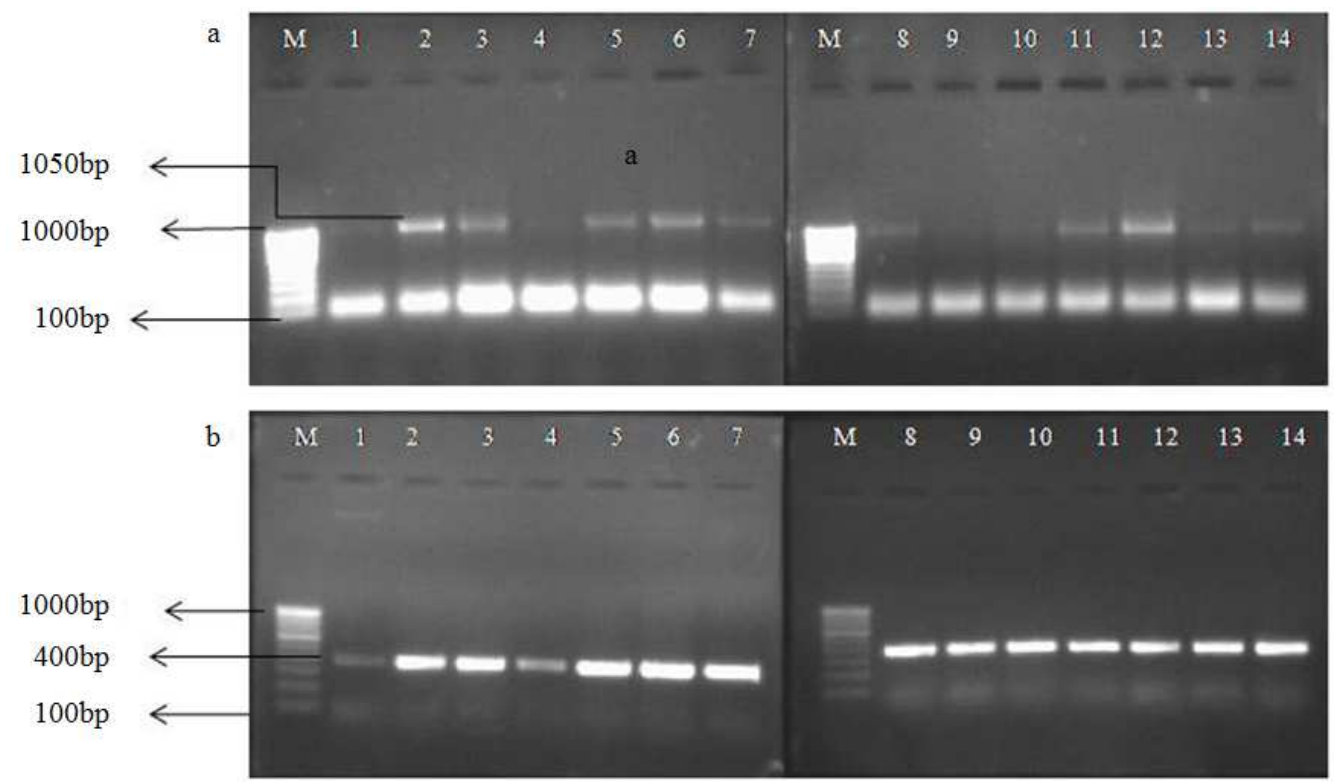

Fig. 1. Lane M- Marker 100-1000 bp. 1a-amplification of 16S rRNA gene, amplicon-1050bp; 1b-amplification of rnpB gene, amplicon-400bp; Note: Distinct bands indicate the amplification of 16S rRNA and rnp B genes of Aeromonas isolates

\section{Minimum Inhibitory Concentration of Metals}

\section{MIC of Silver Nitrate}

The inhibition of bacterial growth by silver nitrate was observed for different concentrations such as $0 \mu \mathrm{M}$, $10 \mu \mathrm{M}, 30 \mu \mathrm{M}, 50 \mu \mathrm{M}, 100 \mu \mathrm{M}, 150 \mu \mathrm{M}, 200 \mu \mathrm{M}$ and $250 \mu \mathrm{M}$. The LB agar without silver nitrate was used as a control. At $250 \mu \mathrm{M}$ concentration, none of the isolates exhibited the resistance to silver nitrate. About $14 \%$ showed resistance to $200 \mu \mathrm{M}$ concentration of silver nitrate, which comprises $11 \%, 18 \%$ and $15 \%$ of isolates isolated from fish, soil and clinical sources, respectively. At $150 \mu \mathrm{M}$ concentration of silver nitrate, $49 \%$ of isolates showed resistance among which, 52\%, 50\% and $33 \%$ of fish, soil and clinical isolates, respectively. Whereas, at $100 \mu \mathrm{M}$ and $50 \mu \mathrm{M}$ concentrations of silver nitrate, $92 \%$ and $98 \%$ of resistant isolates were observed. However, the minimal concentrations of silver nitrate $(10 \mu \mathrm{M}$ and $30 \mu \mathrm{M})$ do not interfere with the growth of the isolates.

\section{MIC of Copper Sulphate}

Inhibition of bacterial growth was observed on LB agar medium supplemented with $0 \mathrm{mM}$ to $7 \mathrm{mM}$ of copper sulphate concentrations. None of the test isolates showed resistance to $7 \mathrm{mM}$ concentration of copper sulphate. At the concentration of $6 \mathrm{mM}, 25 \%$ of the isolates showed resistance to copper sulphate, among which $26 \%, 23 \%$ and $21 \%$ from fish, soil and clinical isolates, respectively. About $63 \%$ of the isolates $(63 \%$ of fish and soil isolates and $70 \%$ of clinical isolates) showed resistance to $5 \mathrm{mM}$ concentration of copper sulphate, whereas at $4 \mathrm{mM}$ concentration of copper sulphate, $97 \%$ of the isolates exhibited growth. As the lower concentrations of copper sulphate $(1 \mathrm{mM}, 2 \mathrm{mM}$ and $3 \mathrm{mM}$ ) do not have much effect, hence all the isolates exhibited the growth on LB agar plate.

\section{silP Gene}

The gene coding for silver resistance (silP) was screened in all the isolates which is of $1200 \mathrm{bp}$. About 62 isolates $(70 \%)$ were found to be conserved with this gene. Of which, about $81 \%, 61 \%$ and $27 \%$ of isolates from fish, soil and clinical isolates, respectively were conserved with silP gene. The silP gene was highly conserved among the fish isolates when compared to soil and clinical isolates. The presence of silP gene do not have complete role in existence of silver resistance among the isolates screened for varying concentrations of silver nitrate except for some isolates. The presence of resistance gene and the development of silver resistance were not in correlation in all the isolates. Few of the 
isolates posses the silP gene but it could not resist the higher concentrations of silver and fewer shows the resistance even at higher concentrations of silver without the presence of silP gene, which indicates that some other components in silver resistance gene cluster may plays vital role in development of resistance towards silver.

\section{copA Gene}

The presence of copper resistance ( $\operatorname{copA})$ was screened in all the isolates used in this study. Of the 88 isolates screened for copA gene coding for copper resistance (1300 bp), 38 isolates were found to be conserved with this gene. The copA gene was highly conserved among the fish isolates when compared with soil and clinical isolates since, among $43 \%$ existence, $51 \%, 17 \%$ and $45 \%$ was conserved in fish, soil and clinical isolates, respectively. As like the case of silver resistance, the presence of copA gene do not have complete role in existence of copper resistance among the isolates screened for varying concentrations of copper sulphate except for some isolates. So the complete cluster of copper resistance genes should be studied for determining the exact component which favours the microbes to resist copper.

\section{Discussion}

\section{Incidence of Aeromonas Isolated from Various Sources}

In the present investigation the prevalence of Aeromonas spp. was recorded in marine fish intestine, soil and clinical (diarrhoeal) sources. A total of 130 samples were processed and about $68 \%$ showed positive for Aeromonas. Higher prevalence of Aeromonas spp. was observed in fish samples when compared to other samples used in this current research, which indicates the opportunistic nature of Aeromonas spp. and it was also a normal flora of fish intestine. It was reported that fish may also be a vehicle for pathogenic bacteria naturally occurring in aquatic environments referred to as indigenous or derived from polluted waters and or from post capture contamination, storage and handling. Joseph et al. (2013) screened for the occurrence of Aeromonas spp. in tropical seafood, aquafarms and mangroves of Cochin coast in South India and they recovered $11 \%$ of Aeromonas spp. by $16 \mathrm{~S}$ rDNA sequence analysis. In the present study about 53\% of Aeromonas spp. was recorded in soil samples, which indicates aeromonads are ubiquitous in occurrence. The variability in the prevalence among West coast and east coast regions of South India may be due to many reasons like river flow and anthropogenic activities.

In the current research $31 \%$ of the diarrhoeal samples were found to be contaminated with aeromonads. The prevalence of Aeromonas spp. among clinical isolates were found to less when compared with other sources. This was supported by Oberhelman and Taylor (2000), who reported that the isolation rate of Aeromonas in many developing countries may range from 5 to $28 \%$ in clinical isolates. Similarly, the occurrence of A. hydrophila in acute gasteroenteritis among children was reported in the Coimbatore region, Tamil Nadu by Subashkumar et al. (2004), where the clinical isolates were collected in the present study. Of the 216 samples they collected, (10\%) were positive for $A$. hydrophila.

\section{Antibiotic Sensitivity}

In recent years development of resistant or multidrug resistant pathogens has become a major problem in India and many countries (WHO, 2013). Bacterial resistance is closely associated with the use of antimicrobial agents in clinical practice. The aeromonads have been regarded as universally resistant to penicillins (penicillin, ampicillin, carbenecillin and ticarcillin) for quite a long time. In the present study the utmost resistance was found to be developed against cephalothin by the isolates and least resistance was shown towards aztreonam. All the isolates were found to be sensitive to chloramphenicol and gentamicin. The F55 isolate obtained from fish showed resistance towards a maximum of seven antibiotics. Multidrug resistance was shown by most of the isolates. With regard to amoxyclav, cefpodoxime, cephalothin and vancomycin, higher frequency of antibiotic resistance was recorded among the clinical isolates. All the isolates were found to be sensitive to chloramphenicol and gentamicin.

\section{Minimum Inhibitory Concentration of Metals}

Although some heavy metals are important and essential trace elements, at high concentrations most of them can be toxic to microbes. Silver et al. (1989) reported that most of the bacteria developed resistance mechanisms in order to survive the high concentrations of metals in the environment. Miranda and Castillo (1998) isolated antibiotic and metal resistant Aeromonas isolates from polluted and unpolluted waters.

In the present study, the minimum inhibitory concentration of silver nitrate towards the Aeromonas isolates used in this study is $250 \mu \mathrm{M}$. Among the isolates screened the clinical isolates have shown constant resistance till $150 \mu \mathrm{M}$, which indicates the prevalence of high silver resistance isolates from clinical source. The minimum inhibitory concentration of copper sulphate towards the Aeromonas isolates used in this study is 7 $\mathrm{mM}$. From the results it is evident that high copper resistant isolates were predominant among the clinical and fish isolates. Several of the silver-resistant strains have been collected from silver-treated patients at burn centres, where these strains have sometimes caused outbreaks (Pirnay et al., 2003). Pike et al. (2002) screened for silver resistance on MHA containing 50 
$\mu \mathrm{M}, 200 \mu \mathrm{M}, 300 \mu \mathrm{M}$ and $500 \mu \mathrm{M}$ AgNO3 and their results correlate with the results of present study.

In the present investigation further silver (silP) and copper (copA) resistance genes which are of $1200 \mathrm{bp}$ and $1300 \mathrm{bp}$, respectively were screened in all the isolates. The silP gene was conserved in $70 \%$ isolates and cop $\mathrm{A}$ gene in $43 \%$ of the isolates. In both the cases of silP and copA resistance genes, higher prevalence was noticed in fish isolates when compared with the other isolates.

\section{Conclusion}

The genus Aeromonas is one of several medically important genus that have become an increasingly troublesome group due to its pathogenesis in human and in aquatic life. The emergence of antibiotic resistance in bacterial populations due to abuse of antibiotics is a major problem in the current situation. In the present study metal resistance of Aeromonas isolates were recorded from diverse sources. This study will be helpful to distinguish the virulent strains from normal Aeromonas flora.

\section{Acknowledgment}

Authors are thankful to Secretary, Principal and Department of Biotechnology of Kongunadu Arts and Science College for providing facilities and encouragement to carry out this research work.

\section{Conflict of Interest}

The authors declare that they have no conflict of interests.

\section{Author's Contribution}

Ramasamy Amsaveni: Participated in all experiments, coordinated the data-analysis and contributed to the writing of the manuscript.

Muthusamy Sureshkumar: Participated in all experiments, coordinated the data-analysis and contributed to the writing of the manuscript.

Joseph Reshma Mary: Participated in performing molecular experiments.

Umapathy Indra: Participated in writing this research paper.

Govindasami Vivekanandhan: Designed the research plan and organized the study.

\section{Ethical Statement}

The authors declare that the manuscript has not been submitted to more than one journal for simultaneous consideration, has not been published previously, none of the data have been fabricated or manipulated.

\section{References}

Alvarez, J.D., C.P. Agurto, A.M. Alvarez and J. Obregon, 2004. Resistencia antimicrobiana en bacterias aisladas de tilapias, agua y sedimento en Venezuela. Revista Científica.

Ashdown, L.R. and J.M. Koehler, 1993. The spectrum of Aeromonas-associated diarrhea in tropical Queensland, Australia. Southeast Asian J. Trop. Med. Public Healt, 24: 347-353. PMID: 8266241

Baker-Austin, C., M.S. Wright, R. Stepanauskas and J.V. McArthur, 2006. Coselection of antibiotic and metal resistance. Trends Microbiol., 14: 176-182. DOI: 10.1016/j.tim.2006.02.006

Beveridge, T.J. and R.J. Doyle, 1989. Metal Ions and Bacteria. 1st Edn., Wiley, New York, ISBN-10: 0471629189, pp: 461.

Chandra, R. and S. Monica, 2011. Influence of lignin, pentachlorophenol and heavy metal on antibiotic resistance of pathogenic bacteria isolated from pulp paper mill effluent contaminated river water. J. Environ. Biol., 32: 739-745. PMID: 22471210

Joseph, A.V., R.S. Sasidharan, H.P. Nair and S.G. Bhat, 2013. Occurrence of potential pathogenic Aeromonas species in tropical seafood, aquafarms and mangroves off Cochin coast in South India. Vet. World, 6: 300-306.

DOI: $10.5455 /$ vetworld.2013.300-306

Ko, W.C., K.W. Yu, C.Y. Liu, C.T. Huang and H.S. Leu et al., 1996. Increasing antibiotic resistance in clinical isolates of Aeromonas strains in Taiwan. Antimicrob Agents Chemother, 40: 1260-1262. PMID: 8723478

Lee, M.F., C.F. Peng, Y.H. Lin, S.R. Lin and Y.H. Chen, 2008. Molecular diversity of class Iintegrons in human isolates of Aeromonas spp. from southern Taiwan. Jpn. J. Infec. Dis., 61: 343-349. PMID: 18806339

Levy, S.B., 1992. The Antibiotic Paradox. 1st Edn., Plenum Press, New York, pp: 279.

Miranda, C.D. and G. Castillo, 1998. Resistance to antibiotic and heavy metals of motile aeromonads from chilean freshwater. Sci. Total Environ., 224: 167-176. DOI: 10.1016/S0048-9697(98)00354-4

Montuelle, B., X. Latour, B. Volat and A.M. Gounot, 1994. Toxicity of heavy metals to bacteria in sediments. Bull Environ. Contam Toxicol., 53: 753-758. DOI: $10.1007 /$ BF00196950

Oberhelman, R.A. and D.N. Taylor, 2000. Campylobacter infections in developing countries. Washington. Am. Soc. Microbiol., 2: 139-153.

Odeyemi, O.A., A. Asmat and G. Usup, 2012. Antibiotics resistance and putative virulence factors of Aeromonas hydrophila isolated from estuary. J. Microbiol. Biotechnol. Food Sci., 1: 1339-1357. 
Parker, J.L. and J.G. Shaw, 2010. Aeromonas spp. Clinical microbiology and disease. J. Infect., 62: 109-118. DOI: $10.1016 /$ j.jinf.2010.12.003

Pettibone, G.W., J.P. Mear and B.M. Sampsell, 1996. Incidence of antibiotic and metal resistance and plasmid carriage in Aeromonas isolated from brown null head (Ictalurus nebulosus). Lett. Appl. Microbiol., 23: 234-240.

DOI: 10.1111/j.1472-765X.1996.tb00073.x

Pike, R., P. Stapleton, V. Lucas, G. Roberts and R. Rowbury et al., 2002. Effect of medium composition on the susceptibility of oral streptococci to mercuric chloride. Curr. Microbiol., 45: 272-276. DOI: 10.1007/s00284-002-3754-1

Pirnay, J.P., D. De Vos, C. Cochez, F. Bilocq and J. Pirson et al., 2003. Molecular epidemiology of Pseudomonas aeruginosa colonization in a burn unit: Persistence of a multidrug-resistant clone and a silver sulfadiazine-resistant clone. J. Clin. Microbiol., 41: 1192-1202.

DOI: $10.1128 /$ JCM.41.3.1192-1202.2003

Pizzaro-Cerda, J. and P. Cossart, 2006. Bacterial adhesion and entry into host cells. Cell, 124: 715-727. DOI: 10.1016/j.cell.2006.02.012

Saidi, N., R. Lagha, F.B. Abdallah, K.B. Rokbani and A. Bakhrouf, 2013. Slime producing, heavy metals and antibiotics resistance in Aeromonas hydrophila isolated in Tunisia. Afr. J. Microbiol. Res., 7: 5697-5708.
Silver, S., T.K. Misra and R.A. Laddaga, 1989. Bacterial Resistance to Toxic Heavy Metals. In: Metal Ions and Bacteria, Beveridge T.J. andR.J. Doyle(Eds.), Wiley, New York, ISBN-10: 0471629189, pp: 461.

Sinha, S., T. Shimada, T. Ramamurthy, S.K. Bhattacharya and S. Yamasaki et al., 2004. Prevalence, serotype distribution, antibiotic susceptibility and genetic profiles of mesophilic Aeromonas species isolated from hospitalized diarrhoeal cases in Kolkata. Indian J. Med. Microbiol., 53: 527-534.

DOI: $10.1099 / \mathrm{jmm} .0 .05269-0$

Subashkumar, R., T. Thayumanavan, G. Vivekanandhan and P. Lakshmanaperumalsamy, 2006. Occurrence of Aeromonas hydrophila in acute gasteroenteritis among children. Indian J. Med. Res., 123: 61-66. PMID: 16567870

Vivekanandhan, G., K. Savithamani, A.A.M. Hatha and P. Lakshmanaperumalsamy, 2002. Antibiotic resistance of Aeromonas hydrophila isolated from marketed fish and prawn of South India. Int. J. Food Microbiol., 76: 165-168. DOI: $10.1016 /$ S0168-1605(02)00009-0

Woods, E.J., C.A. Cochrane and S.L. Percival, 2009. Prevalence of silver resistance genes in bacteria isolated from human and horse wounds. Vet. Microbiol., 138: 325-329.

DOI: $10.1016 /$ j.vetmic. 2009.03 .023

WHO, 2013. World Health Organization. 